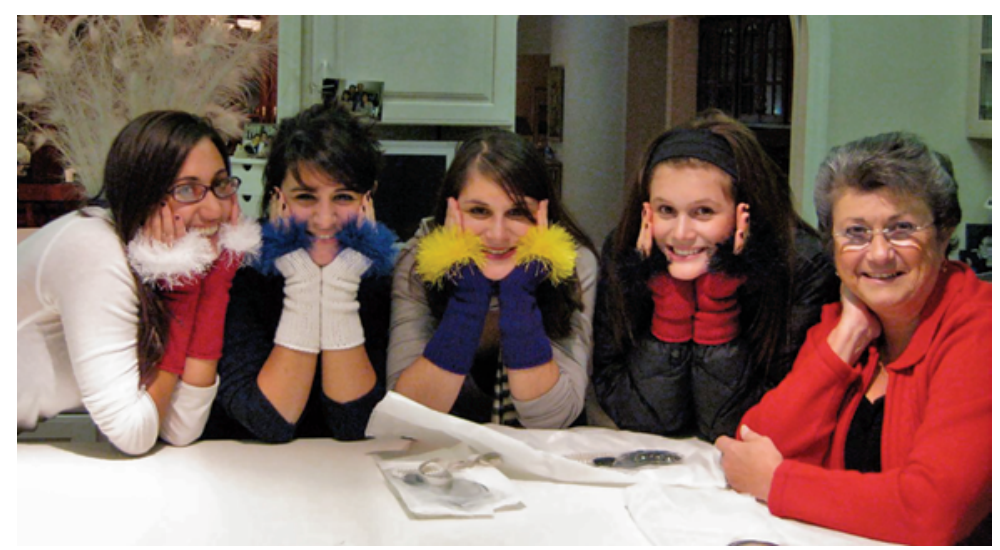

Figure 22

Doris and four granddaughters, Haley, Elyse, Michelle, and Vivian.

\section{Conclusion}

Frank, we thank you for your leadership, your inspiration, and your friendship. And today, we celebrate with you your receipt of the Kober Medal.

\section{Acknowledgments}

I thank Drs. Allyn Mark and Donald Heistad for helpful comments and discussions.

1. Abboud FM, Huston JH. The effects of aging and degenerative vascular disease on the measurement of arterial rigidity in man. J Clin Invest. 1961;40(6):933-939.

2. Abboud FM, Huston JH. Measurement of arterial aging in hypertensive patients. J Clin Invest. 1961;40(10):1915-1921.

3. Huston JH, Abboud FM. Measurement of arterial aging in relation to diabetes mellitus. Circulation. 1962;25:938-946.

\title{
Acceptance of the 2009 George M. Kober Medal
}

\author{
François Abboud
}

M There ought to be a blessing that says, "May you live long enough to have your mentee become your mentor." As a good mentor, Mike made me look pretty good ... with limited material! But you should also see the amount of red ink that he left on my last manuscript.

So, President Elliott Keiff, President-Elect Francis Collins, members of the AAP Council, my academic family, my dear friend Mike, my precious wife Doris, my children, and grandchildren, I have been wondering since Judy Swain called me about my selection a few months ago, how was that possible? After all, there is nothing in my academic pedigree that is in any way close to that of the academic giants who have been so honored. Egypt, Milwaukee, Iowa City. No East Coast, no West Coast, just the Middle East and the Midwest.

So, how could I possibly express my true feelings? A young medical graduate, married just two weeks earlier to a beautiful young bride - she was still 18 - brings her

This article is adapted from a presentation at the Association of American Physicians Annual Meeting, April 26, 2009, in Chicago, Illinois, USA.

Address correspondence to: François M. Abboud, Department of Internal Medicine, University of Iowa College of Medicine, 616 MRC, Iowa City, Iowa 52242 1009, USA. Phone: 319.335.7708; Fax: 319.335.6969; E-mail: francois-abboud@uiowa.edu.

Citation for this article: J Clin Invest. 2010; 120(11):4161-4162. doi:10.1172/JCI45320. from a third world to the shores of liberty. Pockets empty, head full of dreams, heart full of love. And here I am now. How can I stand up here without allowing an exuberant explosion of joy worthy of my true Mediterranean blood to let me jump down from the podium and grab Doris and kiss her ... and maybe even in my confusion, grab Betsy Nable and kiss her? It's too bad that civilization comes at the price of abandonment of exhilarating outbursts! Oh how I miss my childhood!

As it turns out there are other voices stirring in me: those of modesty and gratitude that quickly displace this prideful interlude. The Kober Medal really transcends what might have been accomplished. It speaks to me and Doris of the good fortune that first brought us to the US, the richest country on Earth, not for its material wealth but for the values and character of its people. A country that honors not just individual fulfillment, but the struggle to realize the very best that is in us and in those around us as we pursue our God-given talents.

If any of you in the audience, particularly the young physician-scientists, are wondering if you could be up here some day, the answer is, "Yes, you can. Just go to Iowa."

Doris and I have told our grandchildren dozens of times, "There is no place on Earth that would have extended the arms of opportunity and embraced your grandparents as fully, as fairly, and as freely as we have been." Whatever genius drives the
American spirit, with the audacity of its hope and the assertiveness of its individual rights, should be treasured and nurtured if the honor of the human spirit is to remain alive and well for our grandchildren.

It all started, as you heard, in Cairo: a chance encounter with a Fulbright scholar from Manitowoc, Wisconsin; a fateful presidential act by Dwight Eisenhower in 1956 that declared us immigrants; and a chance meeting with Jack Eckstein, a young established investigator of the American Heart Association. To Jack Eckstein, my mentor and my friend of 49 years, I owe so much of what I am. Once my mentor, always my mentor! If there is a cloud in my sky today, it is that Jack cannot be here because of health reasons.

He convinced me not to go to New York to work with Andre Cournand (the Nobel laureate) at Bellevue and to visit Iowa City instead. I went to Iowa City on a snowy, cold December day, visited an archaic hospital, and made up my mind to stay. It could not have been the weather, or the facilities, or the salary, or the rank. They didn't even show me any laboratories. But I liked the people in Iowa.

They gave me a legacy - a legacy of academic excellence. All I had to do after that was to nurture that legacy and let it grow.

Bill Bean made me chief of the Coronary Care Unit in the 60s. In 1970, Clifton became chairman and appointed me chief of Cardiology and six years later in 1976, 
Dean Eckstein made me chairman of Internal Medicine. They handed me promises, which they kept, but it took the genius of dozens of department leaders and division directors and hundreds of faculty recruited and nurtured over more than three decades to build the Cardiovascular Center and the Department of Internal Medicine into the temples of excellence they are. Our challenge was first to attract candidates to Iowa, and once there, we worked our special magic that kept most of them in Iowa. We called it "Iowa glue": the glue of sharing, helping, working together, and having fun together. I would not be standing here without the loyal support of each and every one of them.

Perhaps the greatest opportunity of my life has been my chairmanship of the Department for 26 years and the incomparable privilege it represented. So when I was asked by my faculty at the end of my term what I would like the last impression of my headship to be, I answered, "not my grants, not my national recognition, not even those impressive departmental statistics. The measure of my book," I told my faculty, "is them; any legacy I leave is in their dreams, their aspirations, their vision, and their future."

The richness of such a legacy as many of you know is in the rewards we seek and ideals we share. Allow me to relate a brief anecdote about one of my most cherished rewards: a letter I received from Ann Hederman, a graduate of our residency program. She writes, "It has been five years since I completed my training at the University of Iowa. I know that you have seen many trainees go through the training program, and I do not expect that you will remember me. I did, however, want to take the opportunity to write to you and let you know how grateful I am for the training I received there."
She continues, "I remember my first day of orientation for internship when you spoke to my class and said that when we get to the point that it became a habit for us to call in, before we went to sleep every night, to check on our patients, then we would have become the physicians you hoped that we would become. Actually," she continued, "I think we all thought maybe you were a little bit crazy. However, by the time I left Iowa I was indeed doing that and continued to do it at the institution where I went to pursue my career." My friends, I hope you agree, as I feel, that Ann's letter and in particular the part about my being a little bit crazy, is a treasure. It tells of the power, privilege, and true rewards of being a teacher.

So the richness of our legacy is in the rewards we seek. It is also in the ideals we impart. I hope you will let idealism shape your students' motives and their character even when expediency has to shape their actions.

Remind them that the miracles of medicine need a heart, not just a mind; they need the hand of compassion. What mind and science cannot cure, a heart and a soothing hand can miraculously heal. "No man or woman should be without a heart or without an ideal." William Osler frequently urged idealism by saying, "not that we all live up to the highest ideals, far from it - we are only human. But we have ideals, which means much, and they are realizable, which means even more."

Let me now end as I started, with gratitude. I am deeply grateful.

Grateful to my children, Mary, Susan, Nancy, and Tony, who spent more time waiting for me than with me and are still willing to let me grandfather their eight children and allow me to redeem myself. So, with your indulgence, may I ask my children Mary, Susan, Nancy, Tony, and his wife Kelli to please stand; and also Haley, Elyse, and Michelle-my grandchildren. Please stand and let me declare that you and the missing five grandchildren - Vivian, Henry, Landon, Lexi, and Hunter have been a source of great joy and make us feel very proud. Thank you for being here.

I am also grateful to three very special mothers: first, my mother, who has always reminded me that "Health is a crown on the head of the healthy, visible only to the sick. Once we lose that crown, we want to regain it at any cost!"

The second mother is my children's mother, Doris, who made this event, as well as everything else in our family life, possible. The mother of Hippocrates told her son: "Hippocrates, don't always be a physician. The help you have needed is the help only a wife could give you. Through her you would learn the other half of life. Without her, you may live to be only half a man." Now I say to Doris, "Doris, the help I have needed is the help only you could give me. Through you I learned the other half of life. Without you, I may have lived to be only half a man."

The third mother has been an inspiration. One of the most treasured gifts I received from my children was a crystal sailboat on the occasion of my 70th birthday. On it there is an inscription that refers to a quote from Mother Teresa that I had frequently repeated to them. The inscription reads, "Thank you, Dad, for teaching us that we can do no great things, but small things with great love."

Finally, I am grateful in the end to all of you. I have received much more than I have given and more than I deserve and my only wish is that we all do a million small things with great love.

Thank you. 